UDC: $582.635 .3-119$

615.322:582.635.3

COBISS.SR-ID: 227887628

Original research paper

Acta Agriculturae Serbica, Vol. XXI, 41 (2016); 25-35

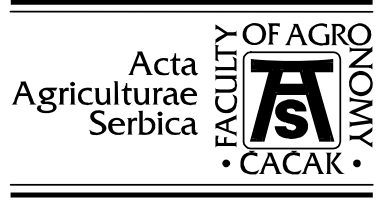

\title{
Phytochemical profile and biological potential of mulberry teas (Morus nigra L.)
}

\author{
Slađana Čestić ${ }^{1}$, Marija Radojković ${ }^{1}$, Aleksandra Cvetanović ${ }^{1}$, \\ Pavle Mašković ${ }^{2}$, Saša Đurović ${ }^{1}$ \\ ${ }^{1}$ University of Novi Sad, Faculty of Technology Novi Sad, Bulevar cara Lazara \\ 1, Novi Sad, Serbia (*ramarija@uns.ac.rs) \\ ${ }^{2}$ University of Kragujevac, Faculty of Agronomy Čačak, Cara Dušana 34, Čačak, \\ Serbia
}

\begin{abstract}
Black mulberry is the most medicinally important plant of the genus Morus. This study examines the chemical composition, antioxidant, antimicrobial and cytotoxic activity of mulberry leaves tea. The tea drinks were prepared in water $\left(70,80,90^{\circ} \mathrm{C}\right.$ and boiling temperature). This study has shown that mulberry teas have high antioxidant, antimicrobial and cytotoxic activity. Experimental investigation has shown that the best conditions for preparing mulberry tea are with boiling water. Mulberry teas could be regarded as a promising source of bioactive natural compounds, which can be used both as a food supplement and herbal remedy.
\end{abstract}

Key words: Morus nigra, tea, phytochemical profile, biological potential.

\section{Introduction}

From the ancient times up to the present day medicinal plants have been used as an essential resource of health benefit compounds (Vidović et al., 2013). Eastern countries have been using herbal remedies to treat infections, ailments and diseases. Herbal remedies are often consumed in the form of tea, i.e. an

Received: 1.4.2016. Accepted: 11.06.2016. 
infusion of dried plant parts steeped in boiling water (Chan et al., 2010: PiljacŽegarac et al., 2013; Šamec et al., 2010). They do not have any particular nutritional value; also constitute an important source of antioxidants (Warren, 1999). On the other hand, herbal infusions and teas could be taken as a good complement of the antioxidants intake in the human diet (Alarcon et al., 2008). Antioxidants are capable of stabilizing, or deactivating free radicals before the latter attack cells and biological targets. They are therefore critical for maintaining optimal cellular and systemic health and well-being (Percival, 1998: Atoui et al., 2005). Today tea is used as a beverage and as a source of health benefit compounds. Due to the awareness of health benefit compounds, consumption of tea is becoming more and more popular in all world countries, including Serbia (Vidović et al., 2013). Many therapeutic properties such as neuroprotective, cardioprotective, chemoprotective, anticarcinogenic, hepatoprotective and anti-inflammatory have been attributed to herbal preparations (Campanella et al., 2003; Visioli et al., 2000), including teas. In Serbia the production of teas and other herbal products have been increased at a rate of $10 \%$ annually (Vidović et al., 2013).

Morus genus is composed of 24 species and more than 100 known variations (Ahmet et al., 2011). Mulberry possesses a long usage history in folk medicine, while almost all parts of the plant exhibit certain level of biological activity. Many biological components such as moranolin, albafuran, albanol, morusin, kuwanol, calystegin and hydroxymoricin have been isolated from mulberry plant and possess significant role in the pharmaceutical industry (Bose, 1989). Due to high content of polyphenolic compounds and bio-potential, this plan becomes more and more interesting and significant for scientific world (Ercisli et al., 2010, Radojković, 2012). Leaves of black mulberry have been used as insect feed in the silk industry in Asian countries. Preparations obtained from leaves of this plant was used for thousands of years for cough suppression, treatment of high sugar level in the blood, different inflammatory treatment, high blood pressure treatment and cancer treatment (Ahmed et al., 2011; Radojković, 2012). This plant is widespread in Serbia, but insufficiently exploited natural resource.

In order to estimate biological activity of black mulberry tea, prepared samples were tested using DPPH assay and assays of antimicrobial and cytotoxic activity (MTT assay). Total phenolics and flavonoids contents were determined, while influence of temperature of water on their content was also estimated.

\section{Materials and methods}

\section{Chemicals and microorganisms}

1,1-Diphenyl-2-picryl-hydrazyl-hydrate (DPPH), Folin-Ciocalteu reagent and $( \pm)$-catechin were purchased from Sigma (Sigma-Aldrich GmbH, Sternheim, Germany). Gallic acid was purchased from Sigma (St. Louis, MO, USA). All 
other chemicals and reagents were of analytical reagent grade. The following bacteria: Staphylococcus aureus ATCC 25923, Klebsiella pneumoniae ATCC 13883, Escherichia coli ATCC 25922, Proteus vulgaris ATCC 13315, Proteus mirabilis ATCC 14153, Bacillus subtilis ATCC 6633, and fungi; Candida albicans ATCC 10231 and Aspergillus niger ATCC 16404. The fungi were cultured on potato-glucose agar for 7 days at room temperature of $20{ }^{\circ} \mathrm{C}$ under alternating light and dark conditions. They were recultured on a new potatoglucose substrate for another 7 days. The culturing procedure was performed four times until pure culture was obtained. The identification of the test microorganisms was confirmed by the Laboratory of Mycology, Department of Microbiology, Torlak Institute, Belgrade, Serbia.

\section{Plant material}

In this research dried plant material of the commercially available Morus nigra L. leaves was used (Adonis D.O.O., Sokobanja). The samples of mulberry leaves were dried naturally (in the shade, on draft) during one month and grounded in a blender before the extraction. Mean particle size was determined using sieve sets (Erweka, Germany). The mean particle size of the plant samples was $1.26 \pm 0.07 \mathrm{~mm}$.

\section{Preparation of tea samples}

Leaves of black mulberry ( $2 \mathrm{~g})$ were topped with water $(200 \mathrm{~mL})$ at different temperatures $\left(70,80,90{ }^{\circ} \mathrm{C}\right.$ and boiled water). After 10 minutes the beverages were filtrated. Obtained extracts were used for further analysis.

\section{Determination of total phenolics and flavonoids content}

Total phenolics content (TPC) in tea and extracts were determined using the Folin-Ciocalteu reagent (Singelton i Rosi, 1965). The reaction mixture was prepared by mixing $0.1 \mathrm{~mL}$ of methanolic solution (concentration $50 \mathrm{mg} / \mathrm{mL}$ ) of extract, $7.9 \mathrm{~mL}$ of distilled water, $0.5 \mathrm{~mL}$ of the Folin-Ciocalteu's reagent and $1.5 \mathrm{~mL}$ of $20 \%$ sodium carbonate. After $2 \mathrm{~h}$, the absorbance at $750 \mathrm{~nm}$ (VIS spectrophotometer, Janwey 6300, Germany) was meassured against the blank solution which had been prepared in a similar manner only with replacing the extract with distilled water. The total phenolic content, expressed as $\mathrm{mg}$ of chlorogenic acid equivalents per g dry mulberry extract (mg CAE/g) and per 200 $\mathrm{mL}$ of tea, was recalculated using calibration curve of chlorogenic acid as standard.

Total flavonoids content (TFC) in tea and extracts were estimated according to previously described method (Markham, 1989). Flavonoids from Morus extracts $(0.2 \mathrm{~g})$ were extracted with $2 \mathrm{~mL}$ of extraction medium $(70 \%[\mathrm{v} / \mathrm{v}]$ 
methanol, 5\% [v/v] acetic acid and 25\% [v/v] distilled water) at room temperature for $60 \mathrm{~min}$. The resulting solution was filtered through Whatman paper No. 4 followed by filtrate volume adjustment to $10 \mathrm{~mL}$. The mixtures were prepared by mixing $5 \mathrm{ml}$ of extract, $1 \mathrm{ml}$ of distilled water and $2.5 \mathrm{~mL}$ of $\mathrm{AlCl}_{3}$ solution $\left(26.6 \mathrm{mg} \mathrm{AlCl} 3 \times 6 \mathrm{H}_{2} \mathrm{O}\right.$ and $80 \mathrm{mg} \mathrm{CH} \mathrm{CH}_{3} \mathrm{COONa}$ dissolved in $20 \mathrm{~mL}$ distilled water). A blank solution was prepared by replacing the extract sample with distilled water. The absorbance of probes and blank probe were measured immediately at $430 \mathrm{~nm}$. Total flavonoid content, expressed as $\mathrm{mg}$ of rutin equivalents per g dry extract (mg RE/g) and per $200 \mathrm{~mL}$ of tea, was calculated from a calibration curve using rutin as standard.

\section{Determination of biological activity of tea samples}

The free radical scavenging activity of mulberry extracts was determined according the previously described method (Espin et al., 2000). Radical scavenging capacity (\%RSC) was calculated using the equation 1 , where As is the absorbance of sample solution and $\mathrm{Ab}$ is the absorbance of a blank sample.

$\% \mathrm{RSC}=100-(\mathrm{As} \times 100) / \mathrm{Ab}$

This activity was also expressed as IC50; which is the concentration of the solution tested required to obtain $50 \%$ of radical scavenging capacity.

Antimicrobial activity was determined according the method described by Satyajit at al. (2007). Minimum inhibitory concentrations (MIC) of the extract and cirsimarin against the test bacteria were determined by microdilution method in 96 multi-well microtiter plates. All tests were performed in Muller-Hinton broth (MHB). A volume of $100 \mu \mathrm{L}$ stock solutions of samples (in methanol, 200 $\mu \mathrm{L} / \mathrm{mL}$ ) and cirsimarin (in $10 \% \mathrm{DMSO}, 2 \mathrm{mg} / \mathrm{mL}$ ) was pipetted into the first row of the plate. $50 \mu \mathrm{L}$ of Mueller Hinton or Sabouraud dextrose broth (supplemented with Tween 80 at a 12 final concentration of $0.5 \%(\mathrm{v} / \mathrm{v})$ for analysis of samples) was added to the other wells. A volume of $50 \mu \mathrm{L}$ from the first test wells was pipetted into the second well of each microtiter line, and then $50 \mu \mathrm{L}$ of scalar dilution was transferred from the second to the twelfth well. $10 \mu \mathrm{L}$ of resazurin indicator solution (prepared by dissolution of a $270-\mathrm{mg}$ tablet in $40 \mathrm{~mL}$ of sterile distilled water) and $30 \mu \mathrm{L}$ of nutrient broth were added to each well. Finally, 10 $\mu \mathrm{L}$ of bacterial suspension and fungi suspension was added to each well. For each strain, the growth conditions and the sterility of the medium were checked. Standard antibiotic amracin was used to control the sensitivity of the tested bacteria, whereas ketoconazole was used as control against the tested fungi. Plates were wrapped loosely with cling film to ensure that bacteria did not become dehydrated and prepared in triplicate, and then they were placed in an incubator at $37^{\circ} \mathrm{C}$ for $24 \mathrm{~h}$ for the bacteria and at $28{ }^{\circ} \mathrm{C}$ for $48 \mathrm{~h}$ for the yeast. Subsequently, color change was assessed visually. Any color change from purple 
to pink or colorless was recorded as positive. The lowest concentration at which color change occurred was taken as the MIC value. The average of 3 values was calculated, and the obtained value was taken as the MIC for the tested compounds and standard drug.

Obtained Morus extracts were evaluated for their cytotoxic activity through their influence on growth of malignantly transformed cell lines using the MTT assay. Malignantly cell lines used it this assay were cell line derived from human rhabdomyosarcoma (RD cell line), cell line derived from human cervix carcinoma (Hep2c cell line) and cell line derived from murine fibroblast (L2OB cell line). Cells were seeded $(104 \mathrm{cell} / \mathrm{mL} ; 100 \mu \mathrm{L} /$ well $)$ in 96 -well cell culture plates (NUNC) in nutrient medium (MEM Eagle supplemented with 5\% (for Hep2c) or $10 \%$ (for $\mathrm{RD}$ and $\mathrm{L} 2 \mathrm{OB}$ ) and grown at $37{ }^{\circ} \mathrm{C}$ in humidified atmosphere for $24 \mathrm{~h}$. Then, corresponding extract (stock solution: $5 \mathrm{mg}$ of extract dissolved in $1 \mathrm{~mL}$ of absolute ethanol) and control (absolute ethanol) diluted with nutrient medium to desired concentrations were added $(100 \mu \mathrm{L} /$ well $)$ and cells were incubated at $37^{\circ} \mathrm{C}$ in humidified atmosphere for $48 \mathrm{~h}$. Pure nutrient medium $(100 \mu \mathrm{L})$ represented positive control for each cell line. After incubation period, supernatants were discarded and 3-[4,5-dimethylthiazol-2-yl]-2,5 diphenyltetrazolium bromide (MTT) (dissolved in D-MEM (Dulbecco's modification of Eagle's medium) in concentration of $500 \mu \mathrm{g} / \mathrm{mL}$ ) was added in each well $(100 \mu \mathrm{L} /$ well $)$. After addition all wells were incubated at $37^{\circ} \mathrm{C}$ in humidified atmosphere for $4 \mathrm{~h}$. Reactions were halted by addition of $100 \mu \mathrm{L}$ of sodium dodecyl sulfate (SDS) $(10 \%$ in $10 \mathrm{mM} \mathrm{HCl})$. After overnight incubation at $37^{\circ} \mathrm{C}$, absorbance was measured at $580 \mathrm{~nm}$ using a spectrophotometer. The number of viable cells per well (NVC) was calculated from a standard curve plotted as cell numbers against absorbance at $580 \mathrm{~nm}$. Corresponding cells (grown in flasks), after cell count by haemocytometer, were used as standards. Standard suspensions were plated in serial dilution, centrifuged at $800 \mathrm{rpm}$ for 10 min and then treated with MTT/D-MEM and $10 \% \mathrm{SDS} / 10 \mathrm{mM} \mathrm{HCl}$ solutions in the same way as the experimental wells (ut supra). The number of viable cells in each well was proportional to the intensity of the absorbed light, which was then read in an ELISA plate reader at $580 \mathrm{~nm}$. Absorbance (A) at $580 \mathrm{~nm}$ was measured $24 \mathrm{~h}$ later. Cell survival (\%) was calculated by dividing the absorbance of a sample with cells grown in the presence of various concentrations of the investigated extracts with control optical density (the A of control cells grown only in nutrient medium), and multiplying by 100 . The blank absorbance was always subtracted from the absorbance of the corresponding sample with target cells. IC50 concentration was defined as the concentration of an agent inhibiting cell survival by $50 \%$, compared with a vehicle-treated control. The results of the measurements are expressed as the percentage of positive control growth taking the cis-diamminedichloroplatinum (Cis-DDP) determined in positive control wells as 100\% growth (Mosmann 1983; Baviskar i sar. 2012). All experiments were done in triplicate. 


\section{Results and Discussion}

Total phenolics and flavonoids contents were investigated in prepared teas from black mulberry leaves together with antioxidant, cytotoxic and antimicrobial activities. In dependence of the used temperature, the TPC was in the range of 21.66$31.77 \mathrm{mg} \mathrm{CAE} / \mathrm{g}$ of plant material or $45.40-63.40 \mathrm{mg} \mathrm{CAE} / 200 \mathrm{~mL}$ of prepared tea (Table 1). From the obtained results it could be noticed that total phenolics content rising with applied temperature. The highest TPC was achieved applying the boiling water. Previous research conducted by Hong et al. (2013) showed that the best temperature range for tea preparation was $90-100{ }^{\circ} \mathrm{C}$ which was in accordance with the results obtained in this study. Obtained results in the case of TFC showed that TFC exhibited different tendency than TPC (Table 1). In the beginning, TFC was increasing with temperature until certain value and then started to decrease. This indicated that at the certain value of temperature decomposition of flavonoid occurred (Lee et al., 2005; Kim et al., 2006).

Table 1. Total phenolic content (TPC) and total flavonoid content (TFC) of mulberry teas

\begin{tabular}{|c|c|c|c|c|}
\hline $\begin{array}{c}\text { Temperature } \\
\left({ }^{\circ} \mathrm{C}\right)\end{array}$ & $\begin{array}{c}\mathrm{TPC} \\
(\mathrm{mg} \mathrm{CAE} / \mathrm{g})\end{array}$ & $\begin{array}{c}\mathrm{TPC} \\
(\mathrm{mg} \mathrm{CAE} / 200 \\
\mathrm{mL})\end{array}$ & $\begin{array}{c}\mathrm{TFC} \\
(\mathrm{mg} \mathrm{RE} / \mathrm{g})\end{array}$ & $\begin{array}{c}\mathrm{TFC} \\
(\mathrm{mg} \mathrm{RE} / 200 \\
\mathrm{mL})\end{array}$ \\
\hline 70 & $21.66 \pm 2.03$ & $45.40 \pm 2.03$ & $24.46 \pm 0.40$ & $48.80 \pm 0.40$ \\
\hline 80 & $26.55 \pm 0.84$ & $53.20 \pm 0.84$ & $27.25 \pm 0.45$ & $54.40 \pm 0.45$ \\
\hline 90 & $29.22 \pm 2.54$ & $58.40 \pm 2.54$ & $22.02 \pm 0.38$ & $44.00 \pm 0.38$ \\
\hline $\begin{array}{c}\text { Boiling } \\
\text { temperature }\end{array}$ & $31.77 \pm 2.52$ & $63.40 \pm 2.52$ & $20.58 \pm 0.90$ & $41.20 \pm 0.90$ \\
\hline
\end{tabular}

Antioxidant activity obtained by DPPH assay was presented in Table 2 . The tea sample prepared using the boiling water exhibited the highest activity (lowest IC50 value) of $0.0724 \mathrm{mg} / \mathrm{mL}$. From the obtained results it could be noticed that with decreasing in temperature antioxidant activity also decrease. Gazzani et al. (1998) concluded that antioxidant activity of fruit juices were stabilized with boiling. Castenmiller et al. (2002) claimed that antioxidant activity of teas depended on thermal processes and plant material.

Table 2. Radical scavenging activity of mulberry teas

\begin{tabular}{|c|c|}
\hline Temperature $\left({ }^{\circ} \mathrm{C}\right)$ & $\mathrm{IC}_{50} \pm \mathrm{SD}(\mathrm{mg} / \mathrm{mL})$ \\
\hline 70 & $0.1060 \pm 0.004$ \\
\hline 80 & $0.0860 \pm 0.004$ \\
\hline 90 & $0.0810 \pm 0.002$ \\
\hline Boiling temperature & $0.0724 \pm 0.001$ \\
\hline
\end{tabular}


Results obtained for antimicrobial activity were presented in Table 3. Presented values showed that prepared tea samples inhibited growth of all tested microorganisms. Minimal inhibitory concentrations (MIC) were in the range of 39.100-156.250 $\mu \mathrm{g} / \mathrm{mL}$ for bacteria and 19.53-78.125 $\mu \mathrm{g} / \mathrm{mL}$ for fungi (Table 3). The highest activity was exhibited against Candidu albicans $(19.530 \mu \mathrm{g} / \mathrm{mL})$ and Klebsiella pneumoniae $(39.100 \mu \mathrm{g} / \mathrm{mL})$. Obtained results showed significant activity against Staphyloccus aureus $(78.125 \mathrm{mg} / \mathrm{mL})$. Exhibited activity was very significant for general characterization of biological activity of mulberry tea samples, takin into account that Staphyloccus aureus showed high resistance against antibiotics especially against $\beta$-lactams and macrolides which is still using in the therapy against bacteria (Garrity et al., 2005). Fukai et al. (2005) showed that chalcomoracin isolated from mulberry leaves exhibited very high antibacterial activity against Staphyloccus aureus $(0.78 \mu \mathrm{g} / \mathrm{mL})$.

Table 3. Minimum inhibitory concentration (MIC) of mulberry teas

\begin{tabular}{|c|c|c|c|}
\hline \multirow{2}{*}{ Microbial strains } & \multicolumn{3}{|c|}{ MIC $(\mu \mathrm{g} / \mathrm{mL})$} \\
\cline { 2 - 4 } & Tea & $\begin{array}{c}\text { Amracin } \\
\text { (standard) }\end{array}$ & $\begin{array}{c}\text { Ketokonazol } \\
\text { (standard) }\end{array}$ \\
\hline $\begin{array}{c}\text { Staphylococcus aureus } \\
\text { ATCC 25923 }\end{array}$ & 78.125 & 0.970 & $/$ \\
\hline $\begin{array}{c}\text { Klebsiella pneumoniae } \\
\text { ATCC 13883 }\end{array}$ & 39.100 & 0.490 & $/$ \\
\hline $\begin{array}{c}\text { Escherichia coli } \\
\text { ATCC 25922 }\end{array}$ & 78.125 & 0.970 & $/$ \\
\hline $\begin{array}{c}\text { Proteus vulgaris } \\
\text { ATCC 13315 }\end{array}$ & 156.250 & 0.490 & $/$ \\
\hline $\begin{array}{c}\text { Proteus mirabilis } \\
\text { ATCC 14153 }\end{array}$ & 156.250 & 0.490 & 1.950 \\
\hline $\begin{array}{c}\text { Bacillus subtilis } \\
\text { ATCC 6633 }\end{array}$ & 78.125 & 0.240 & 0.970 \\
\hline $\begin{array}{c}\text { Candida albicans } \\
\text { ATCC 10231 }\end{array}$ & 19.530 & $/$ & $/$ \\
\hline $\begin{array}{c}\text { Aspergillus niger } \\
\text { ATCC 16404 }\end{array}$ & 78.125 & $/$ & $/$ \\
\hline
\end{tabular}

Results of cytotoxic activity obtained using MTT test were presented in Table 4. Three cell lines were used (Hep2c, RD and $L 2 O B$ cell lines) and tested in vitro. Obtained results were compared with cis-diammindichloroplatinum (cisDPP) activity as standard. From the presented results it might be noticed that prepared tea samples showed certain diversity in capability of inhibition of cell 
lines growth. Exhibited activity was in the range of $22.25-101.25 \mu \mathrm{g} / \mathrm{mL}$. sensitivity of tested cell lines decreased in following order Hep2c cells $>R D$ cells $>L 2 O B$ cells.

Table 4. IC50 values of mulberry teas

\begin{tabular}{|c|c|c|c|}
\hline \multirow{2}{*}{ Sample } & \multicolumn{3}{|c|}{$\begin{array}{c}\mathrm{IC}_{50} \pm \mathrm{SD} \\
(\mu \mathrm{g} / \mathrm{mL})\end{array}$} \\
\cline { 2 - 4 } & Hep 2 cells & $R D$ cells & $L 2 O B$ cells \\
\hline$T e a$ & $22.25 \pm 1.17$ & $30.07 \pm 0.63$ & $101.25 \pm 0.14$ \\
\hline $\begin{array}{c}c i s- \\
\text { diamminedichloroplatinum } \\
\text { (Cis-DDP) }\end{array}$ & $0.94 \pm 0.55$ & $1.40 \pm 0.97$ & $0.72 \pm 0.64$ \\
\hline
\end{tabular}

\section{Conclusion}

Obtained results showed that prepared tea samples of black mulberry leaves possessed high content of polyphenolic compounds. It was also showed that tea samples exhibited high antioxidant, antimicrobial and cytotoxic activity. Proposed water temperature for preparation of the tea was near boiling point. It may be concluded that tea of mulberry leaves, as simplest form of phytopreparation, should be recommended for usage and further examination due to placement of mulberry products in the market as food supplement.

\section{Acknowledgements}

The financial support of the Ministry of Education, Science and Technological development of the Republic of Serbia is gratefully acknowledged (Project No. TR31013).

\section{References}

Ahmed M.A.Abd. El-Mawia, Khaled M. M., Ashraf M.M. (2011). Induction of Biologically Active Flavonoids in Cell Cultures of Morus nigra and Testing their Hypoglicemic Efficacy, Sci Pharm, 79(4): 951-961.

Alarcon E., Campos A.M., Edwards A.M., Lissi E., Lopez-Alarcon M. (2008). Antioxidant capacity of herbal infusions and tea extracts: A comparison of ORACfluorescein and ORAC-pyrogallol red methodologies. Food Chemistry, 107: 11141119.

Atoui A.K., Mansouri A., Boskou G., Kefalas P. (2005). Tea and herbal infusions: Their antioxidant activity and phenolic profile. Food Chemistry, 89: 27-36. 
Baviskar B.A., Khadabadia S.S., Deore S.L., Shiradkar M.R. (2012). Synthesis of clubbed Triazolyl Indeno[1,2-C]Isoquinolines as an Novel Anticancer Agent. Der Pharmacia Sinica, 3:24-30

Bose P.C. (1989). Genetic resources of mulberry and utilization. CSR and TI, Mysore, India, 183-190.

Campanella L. Bonanni A., Tomassetti M. (2003). Determination of the antioxidant capacity of samples of different types of tea or of beverages based on tea or herbal products, using superoxide dismutase biosensor. Journal of Pharmaceutical and Biomedical Analysis, 32: 725-736.

Castenmiller J.J.M., Linssen J.P.H., Heinonen I.M., Hopia A.I., Schwarz K., Hollmann P.C.H., West C.E. (2002). Antioxidant properties of differently pšrocessed spinach products, Nahrung/Food 46 (4): 290-293

Chan E.W.C., Lim Y.Y., Chong K.L., Tan J.B.L., Wong S.K. (2010). Antioxidant properties of tropical and temperate herbal teas. Journal of Food Composition and Analysis, 23: 185-189.

Ercisli S., Tosun M., Duralija B., Voća S., Sengul M., Turad M. (2010). Phytochemical content of some black (Morus nigra L.) and purple (Morus rubra L.) mulberry genotypes, Food Tecnology and Biotechnology, 48:102-106.

Espin J.C., Soler-Rivas C., Wichers H.J. (2000). Characterization of total free radical scavenger capacity of vegetable oils and oil fractions using 2,2-diphenyl-1picrylhydrazyl radical. Journal of Agricultural Food Chemistry, 48: 648-656.

Fukai T., Kiyoshi K., Terada S. (2005). Antimicrobial activity of 2-arylbenzofurans from Morus species against methicillin-resistant Staphylococcus aureus. Fitoterapia, 76:708-711.

Garrity G.M., Bell J.A., Lilburn T. (2005) Class III. Gammaproteobacteria class. nov. In Bergey's Manual of Systematic Bacteriology, Objavljeno u The Proteobacteria, part B (The Gammaproteobacteria), Brenner D.J., Krieg N.R., Staley J.T., Garrity G.M. (eds. 2, vol 2), 1-3, New York, Springer.

Gazzani G., Papetti A., Massolini G., Daglia M. (1998). Antioxidative and pro-oxidant activity of water soluble components of some common diet vegetables and the effect of thermal treatment. Food Chemistry, 6: 4118-4122.

Hong H.C., Li S.L., Zhang X.Q., Ye W.C., Zhang Q.W. (2013). Flavonoids with $\alpha-$ glucosidase inhibitory activities and their contents in the leaves of Morus atropurpurea. Chinese Medicine, 8:19.

Kim E.O., Lee J.Y., Choi S.W. (2006). Quantitative changes in phenolic compounds of safflower (Carthamus tinctorius L.) seeds during growth and processing. Food Science and Nutrition, 11:311-317.

Lee J.Y., Park K.S., Choi S.W. (2005). Changes in flavonoid contents of safflower leaf during growth and processing. Food Science and Nutrition, 10:1-5.

Markham K.R. (1989). Flavones, flavonols and their glycosides. U: Harborne, J.B., Dey, P.M. (Eds.), Methods in Plant Biochemistry, Academic Press, London, 193-237.

Mosmann T. (1983). Rapid colorimetric assay for cellular growth and survival: application to proliferation and cytotoxicity assays. Journal of Immunological Methods, 65:55-63

Percival M. Antioxidants. (1998). Clinical Nutrition Insight, 31: 1-4. 
Piljac-Žegarac J., Šamec D., Piljac A. (2013): Herbal Teas: A Focus on Antioxidant Properties. In Preedy V. (eds), Tea in Health and Disease Prevention, Academic Press, 129-140 pp.

Radojković M. (2012). Ekstrakti duda (Morus spp. Moraceae), sastav, delovanje i primena, Doktorska disertacija, Univerzitet u Novom Sadu, Novi Sad.

Šamec D., Gruz J., Strand M., Kremer D., Kosalec I., Jurišić Grubešić R., Karlović K., Lucic A., Piljac-Žegarac J. (2010). Antioxidant and antimicrobial properties of Teucrium arduini L. (Lamiaceae) flower and leaf infusions (Teucrium arduini L. antioxidant capacity). Food and Chemical Toxicology, 48: 113-119.

Satyajit D, Sarker L.N., Kumarasamy Y. (2007). Microtitre plate based antibacterial assay incorporating resazurin as indicator of cell growth, and its application in the in vitro antibacterial screening of phytochemicals. Methods 42:321-324

Singleton V.L., Rossi J.A. (1965). Colorimetry of total phenolics with phosphomolybdicphosphotungstic acid reagents. American Journal of Enology and Viticulture, 16: 144-158.

Vidović S., Cvetković D., Ramić M., Dunjić M., Malbaša R., Tepić A., Šumić Z., Velićanski A., Jokić S. (2013). Screening of changes in content of health benefit compounds, antioxidant activity and microbiological status of medicinal plants during the production of herbal filter tea. Industrial Crops and Products, 50: 338-345.

Visioli F., Borsani L., Galli C. (2000). Diet and prevention of coronary heart diseases: the potential role of phytochemicals. Cardiovascular Research, 47: 419-425.

Warren, C. P. (1999). Antioxidant effects of herbs. Lancet, 353: 676.

Yang C.S., Landau J.M. (2000). Effects of Tea Consumption on Nutrition and Health. Journal of Nutrition, 130: 2409-2412. 


\title{
FITOHEMIJSKI PROFIL I BIOLOŠKI POTENCIJAL ČAJNOG NAPITKA DUDA (MORUS NIGRA L.)
}

\author{
Slađana Čestić ${ }^{1}$, Marija Radojković ${ }^{1}$, Aleksandra Cvetanović ${ }^{1}$, \\ Pavle Mašković ${ }^{2}$, Saša Đurović ${ }^{1}$ \\ ${ }^{1}$ University of Novi Sad, Faculty of Technology Novi Sad, Bulevar cara Lazara \\ 1, Novi Sad,Serbia (*ramarija@uns.ac.rs) \\ ${ }^{2}$ University of Kragujevac, Faculty of Agronomy Čačak, Cara Dušana 34, Čačak, \\ Serbia
}

\begin{abstract}
Rezime
Crni dud (Morus nigra L.) je medicinski važna biljka iz porodice Morus. U ovom radu ispitan je sadržaj ukupnih fenola i flavonoida kao i antioksidativna, antimikrobna i citotoksična aktivnost čajnih napitaka lista crnog duda. Čajni napitci su pripremani korišćenjem vode različite temperature $\left(70,80,90^{\circ} \mathrm{C}\right.$ i ključala voda). Ispitivanja koja su urađena su pokazala da čajni napitci poseduju visoku antioksidativnu, antimikrobnu i citotoksičnu aktivnost. Najbolje osobine pokazali su napitci pripremani sa ključalom vodom. Čajni napici lista duda se mogu smatrati odgovarajućim izvorom prirodnih bioaktivnih komponenti, koji mogu naći primenu u vidu dodataka ishrani ili herbalnih lekova.
\end{abstract}

Ključne riječi: Morus nigra, dud, čajni napitak, fitohemijski profil, biološka aktivnost. 